\title{
Quit India Movement in Godavari Districts
}

\author{
Dr.D.Anjaneyulu \\ Lecturer in History, D.S. Govt Degree College (W), Ongole
}

\begin{abstract}
The objective of the study is to examine the growth, nature and consequences of the Quit India Movement in Godavari Districts. The people ofEast and west Godavari tookpart in attacking on Railway Stations at Attili, Relangi, Undi.Dendulur, Lankalakoderu, Vendra etc.in this movement.As a part of this movement people attack on police station at Akiveedu, palacol and postoffice at pentapadu.Despite stringent measures were taken by the police, this movement progressed with the spread of prohibited papers.In EastGodavari Kala VenkataRao's Andhra Circular created a new methods of agitation in this movement. Thus the participation of people and students were remarkable in this movement.
\end{abstract}

Keywords: Quit India, Andhra Circular, August Resolution, Do or Die, raid, attack, police station, damages, imprisonment

\section{INTRODUCTION}

The twentieth century was marked by the struggle of nations against alien and autocratic regimes. India was one such nation. It was the first Afro-Asian nation to emerge from colonial control. It was India's national movement which brought oneness among the people of various castes, religious communities, linguistic and cultural groups.

By March 1942 the forces of the British enemy, Japan occupied Singapore, Rangoon and Andamans and even threatened British India's frontiers Anxious to have the full and active cooperation of India in the Second World War, the British Prime Minister Churchill announced in the House of Commons on 11 March 1942, the appointment of Sir Stafford Cripps to visit and get India's support. Cripps arrived in Delhi on 22 March 1942 and on 29 March 1942 he released to the press the draft declaration of the Government wherein it was stated that India would be given dominion status and right to leave even the Common Wealth after the war. A Constituent Assembly would be setup to implement these proposals and The defence of India, during the war, would be under the control of the British, but there would be an Indian as Defence Member. These proposals were, however, rejected by all parties. There was a general mood of frustration in all quarters.

Meanwhile, on April 6, 1942 Kakinada in Andhra was bombed by Japan. The All India Congress Committee met at Allahabad from 29 April to 2 May 1942 and urged for independence. The Congress Working Committee also met at Wardha and passed a resolution on 14 July 1942 calling upon Britain to transfer power and Quit India immediately so that Japanese attack of India could be avoided. As there was no response from Britain the AICC met at Bombay, to endorse the Wardha resolution, under the Presidentship of Maulana Abul Kalam Azad and passed the famous Quit India resolution on 8 August 1942, also known as the "August Resolution" and placed Gandhi in the command of the movement. In his address to the delegates Gandhi urged the people to forget differences between Hindus and Muslims and to think themselves as Indians only. He said "We shall either free India or die in the attempt: We shall not live to see the perpetuation of our slavery". The All India Congress Committee meeting was attended by 250 members. The resolution was moved by Jawaharlal and seconded by Vallabhai Patel. In spite of the resolution Gandhi tried to meet the Viceroy and plead for independence but in vain. On the night of 8 August 1942, Gandhi, Jawaharlal and others were arrested and sent to jail.

\section{The Andhra Circular'}

In Andhra, the Congressmen who were closely watching the developments in the country, including the Allahabad and Wardha meetings and their resolutions drew-up an elaborate plan of action known as 'the Andhra Circular'. In fact, the A.P.C.C had issued a circular popularly known as Kurnool Circular even before the AICC met at Bombay. It was drafted by Kala Venkata Rao of East Godavari District and General Secretary of APCC and was sent on 29 July 1942 for the approval of the CWC. 


\section{Dr.D.Anjaneyulu}

The Circular envisaged a programme of defying prohibitory orders, lawyers to give up practice, students to leave colleges picketing salt and foreign trade and Industry, cutting of the toddy yielding palm trees, travelling without tickets in trains, pulling chains to stop trains and blowing up bridges so that communications might be disrupted and the movement of the army personnel retarded., the cutting of telegraph and telephone wires, non-payment of taxes excepting municipal taxes, picketing of recruitment offices and hoisting of national flag on all government buildings as a sign of independence. The instructions were to carry on the struggle till the finish. "Do or Die" was the slogan

In West Godavari District the masses showed a great sense of patriotism and their dedication to the Gandhian principles. They played the most dominating role. One important aspect in this movement was that the second rank leaders took reins of leadership.

\section{Attack On Railway Stations}

\section{Attili \& Relangi}

Maganti Chakrapani and AB Perraju provoked students of the Board Highschool at Attili with ther speeches. 200 students went to the Attili station on foot, threw away the recods on the platform and burnt them.They went to the Relangi station. Police caught Maganti Chakrapani on $18^{\text {th }}$ August. Students pressurised for his release. He was arrested for one year.

\section{Undi}

Undi, a small village located near Bhimavaram D.Sivaram Sarma excited masses with his speeches. The masses went to the railway station and attacked it and destroyed bloc instruments,telegraph and rails between undi and Akividu.The police filed Charge sheets aganist eleven persons including D.S.Sarma,I.S.Raju G.Venkanna etc. I.Seshagiri Rao, the Divisional Magistrate conducted court proceedings in the Hospital where Lanka Jaggarao was sick and bedridden.He released Jaggarao and sentenced ten others to rigorous Imprisonment.

\section{Dendulur}

Nearly 150 persons went to Dendulur station threw kerosene on the store room and setfire it. The Assistant Station master could not prevent it with limited force of 12 guards. They damaged bloc instruments and a large portion of Station Master Room. The Police enquired and suspected that V. KoteswaraRao should be mainly responsible. The police suspected that Manikyala Rao at kovali should have excited people and found that the real culprit was Dendulur villagers. They removed Vedula Venkataramayya President of Kovali Panchayat. The District Collector decided to collect Rs.1600 for railway station damages from the people of Dendulur. The amount was enhanced by the Madras Government.

\section{Lankalakoderu}

Lankalakoderu, a small village near PalacoleS.V.G.Krishnam Raju popularly known Lankalakoderu ustad played a pivotal role. On12 ${ }^{\text {th }}$ August, people disconnected telegraph wires between lancala koderu and palacole. They burnt station recods. The Tasildar gathered information regading the incident from important persons of the village. At last, the authorities valued and fixed the damages at Rs.2317.

\section{Vendra}

Under the guidance of Bhupatiraju Subbaraju, masses cut telegraph wires between vendra and Bhimavaram. Nearly 200 people went railway station and wrecked the telephone apparatus and broke the station lantern. On $16^{\text {th }} 200$ people arrived and the whole bridge was burnt. On $17^{\text {th }}$ August Police sub-inspector went to raiway station and saw the colossal damage to the railway station. The sub inspector filed cases against D.Subbaraju and S.Venkataraju. They were sentenced one year rigorous imprisonment. The Government collected Rs.3000/ as collective fine. Vendra people encouraged other villages such as palakeru, Mogallu etc to participate in this movement against the British.

\section{Raid on Police Stations}

When Dandu Narayana Raju was arrested, D.Sivaramaraju provoked masses to attack on police station.V, S.Ramayya mobilised 3000 people and attacked Akiveedu police station. They removed police records and burnt them. The rioters burnt large portion of buiding. The masses attacked the quarters of police Sub inspector and police constables. 


\section{Government Offices}

Dandu Narayanaraju has been arrested at powerpetaon $11^{\text {th }}$ August.G.Sree RamaRaju and A.Subbarayudu instigatd masses against Government.They decided to close the local ULCK school.They went to school and asked the Head Master politely to close the school.But He rejected to close it .As a result they broke benches and chairs. The masses proceeded to Revenue Dvisional office for closing it.They convinced the authorities and closed it.They also attacked police stations.Nearly 119 were arrested .47 were convicted.

\section{Post Office at Pentapadu}

The masses attacked the sub post office and broke open with crow bars .They smashed the glass planes furniture bores, records etc.Tadepalli police arrested 12 persons. The arrested persons were B.S.Narayanareddy, M.Durga prasad, Pasha Sahebetc.The total value of property damaged at post office was Rs.1030. On the whole, collective fines were levied over the people to the tune of Rs.3000.

\section{Secret Meetings and Spread of Prohibited Literature}

The Congress Leaders held meetings secretly.A.V.Subbarao, M.Narayanarao.M.Rangaiah conducted meetings secretly.But Police scented it and arrested M.Narayanarao.They also arrested.P.Ramayya and N.P Venkaiah.M.Rangaiah was arrested because he procured Communist literature from Bombay..The Magistrate sentenced G.Satyanarayana to an imprisonment of 6 weeks for instigating students against the government.Inspite of the stringent measures taken by police; the Quit India movement progressed with the spread of prohibited papers.

\section{The Role of Students:}

When Sir Arthur Hope, the Governor visited Kakinada in August, the Municipality made necessary arrangements to extend warm welcome to him.But some students who belonged to the National and Bandaru Lodge tried to spoil it. The Government arrested J.Lokeswararao, Chidanadam and Venkataramana. On $18^{\text {th }}$ August nearly 1000 students participated in a procession at Kakainada.

\section{Conclusion}

West Godavari was the top in evincing extremist Nationalism among two Godavari Districts.AB Perraju, D.Sivarama sarma, ManikyalaRao and K .G.Krishnam Raju gave thought provoking speeches to masses. The masses due to much frustration for the arrest of their leader Gandhiji and others bulged with emotion and setfire to stations.At Pentapadu, 300 students shouting slogans 'Gandhiki Jai' went to PWD office and demaned its officer to resign. But he escaped.The participation of masses and their clash with police. Consequent police firing by the police is another index of the high level of patriotism in these Districts. It would not have come into notice all over India but for the Andhra Circular distributed by Kala Venkatarao, a native of the East Godavari District.He along with K.Linga raju, Pallam raju went to Bombay to attend the AICC Session.The P.R.College Students of Kakinada made loud protests against the Governor Sir Arthur Hope togo back.It shows their support to Gandhiji who was doing fast. Thus the students of East and west Godavari Districts became a force to reckon with.

\section{REFERENCES}

\section{Primary Sources}

[1] Fortnightly Report from the Government of Madras

[2] Letter from the Dt. Collector East Godavari to the Chief Secretary

[3] Letter from the Dt. Superintendent of Police to the Dt.Magistrate Ellore

[4] Andhra Patrika

[5] Krishna Patrika

\section{Secondary Sources}

[1] Anjaneyulu, Kodali, Andhrapradeshlo Gandhiji, 1977

[2] Bipan Chandr, India's Struggle for Independence1885-1947, New Delhi1988.

[3] Mathur, Y.B, Quit India Movement, Delhi, Pragathi Publications, 1979

[4] Rao, P.R History of Modern Andhra, 1988.

[5] Reagani, Sarojini, Highlights ofthe Freedom Movement in Andhra Pradesh, Hyderabad, 1972. 